\title{
Pengaruh Skeptisisme Profesional, Due Professional Care, dan Tekanan Anggaran Waktu pada Kualitas Audit
}

\author{
Ni Putu Ayu Nikita Sari Wulan ${ }^{1}$ \\ Fakultas Ekonomi dan Bisnis \\ Universitas Udayana, Indonesia \\ Email: tatanikita30@gmail.com
}

\author{
I Ketut Budiartha ${ }^{2}$ \\ Fakultas Ekonomi dan Bisnis \\ Universitas Udayana, Indonesia
}

\begin{abstract}
ABSTRAK
Kualitas audit merupakan salah satu aspek penting, karena audit yang berkualitas akan mencerminkan kondisi di lapangan yang sebenarnya. Penelitian bertujuan untuk memberikan bukti secara empiris pengaruh skeptisisme profesional, due professional care, dan tekanan anggaran waktu pada kualitas audit. Penelitian ini dilakukan di Kantor Badan Pemeriksa Keuangan (BPK) RI Perwakilan Provinsi Bali. Jumlah sampel adalah 52 orang auditor, dengan metode non probability sampling dengan teknik sampling jenuh. Pengumpulan data melalui metode survei dengan teknik kuesioner. Teknik analisis yang digunakan adalah analisis regresi linier berganda. Berdasarkan hasil penelitian ditemukan bahwa secara parsial skeptisisme profesional dan due professional care berpengaruh positif dan signifikan terhadap kualitas audit, sedangkan tekanan anggaran waktu berpengaruh negatif dan signifikan terhadap kualitas audit.
\end{abstract}

Kata Kunci: Skeptisisme Profesional; Due Professional Care; Tekanan Anggaran Waktu; Kualitas Audit.

\section{The Effect of Professional Skepticism, Due Professional Care, and Time Budget Pressure on Quality Audit}

\section{ABSTRACT}

Audit quality is one important aspect, because quality audit will reflect the actual conditions on the field. This research is to give the empirical fact of the effect of professional skepticism, due professional care, and time budget pressure on quality audit. The research is taking place at the BPK RI Perwakilan Provinsi Bali. The quantity of the sample is 52 auditors, using of non probability sampling method with the sampling sapurated technique. Questioner technique from the survey method used to collects the datas. Analisys technique that used in this research is multiple linear regression analisys technique. The result of the research showed that the professional skepticism and due professional care significantly give positive effects to the quality audit, meanwhile time budget pressure significantly give negative effects to the quality audit.

Keywords: $\quad$ Professional Skepticism; Due Professional Care; Time Budget Pressure; Quality Audit.

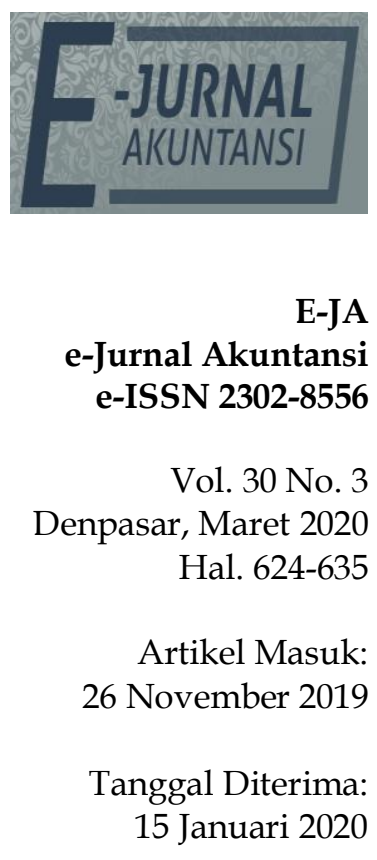




\section{PENDAHULUAN}

Tata kelola keuangan negara merupakan hal yang digunakan sebagai bahan penilaian bagi pembangunan nasional. Tata kelola yang baik akan digunakan untuk mengawasi pengelolaan keuangan negara. Selain itu, tata kelola yang kuat juga menjadi sebuah harapan guna mencegah perilaku menyimpang serta dapat meningkatkan transparansi eksternal tentang apa yang dilakukan oleh instansi maupun perusahaan dan bagaimana mereka melakukannya (Ghafran \& O'Sullivan, 2017). Seluruh instansi negara yang menggunakan keuangan negara harus memiliki laporan keuangan yang menggambarkan praktik transparansi dan dapat dipercaya, serta mempu berkomitmen untuk menegakkan good governance. Good governancemempu tercipta dengan adanya beberapa aspek pendukung, yaitu pengawasan, pengendalian, dan pemeriksaan.

Salah satu proses pemeriksaan adalah audit. Menurut Jusup (2014:10) audit adalah proses untuk memperoleh dan mengevaluasi bukti yang berhubungan dengan tindakan atau kejadian ekonomi guna menentukan tingkat kepatuhannya terhadao kriteria yang ditetapkan. Terdapat dua jenis audit, yaitu audit sektor publik dan audit sektor swasta. Audit sektor publik adalah audit yang dilakukan pada organisasi pemerintahan, sedangkan audit sektor swasta adalah audit yang dilakukan pada perusahaan milik swasta. Badan Pemeriksa Keuangan Republik Indonesia (BPK RI) merupakan salah satu lembaga yang melaksanakan audit pada sektor publik. BPK RI dalam menjalankan tugas harus berpedoman pada Standar Pemeriksaan Keuangan Negara (SPKN). Terdapat tiga hal yang dimuat dalam SPKN yaitu persyaratan profesional pemeriksa, mutu pelaksanaan pemeriksa, dan organisasi pemeriksa dalam melaksanakan pemeriksaan.

Hasil pemeriksaan BPK menunjukkan bagaimana seorang auditor mampu mendeteksi kesalahan dalam laporan keuangan. Tetapi pada kenyataannya, masih terdapat penyimpangan audit yang terjadi. Salah satunya adalah kasus suap yang melibatkan auditor BPK. Emerson Yunthi, selaku aktivis Indonesian Corruption Watch (ICW), menyatakan bahwa antara tahun 2015 hingga Mei 2017, sudah terjadi enam kasus suap yang melibatkan 23 auditor dan pegawai Badan Pemeriksa Keuangan (BPK). Kasus suap tersebut merupakan kasus untuk mendapatkan Opini Wajar Tanpa Pengecualian dan Opini Wajar Dengan Pengecualian, serta untuk mengubah hasil temuan BPK dan memperlancar proses audit yang dilakukan BPK. Nilai kasus suap tersebut berkisar antara Rp80.000.000 sampai dengan Rp1.600.000.000 (Haryadi, 2017). Kasus suap tersebut tentu akan berdampak langsung terhadap kualitas audit yang dihasilkan.

Kualitas audit adalah hal yang sangat penting, sebab audit yang berkualitas akan mencerminkan kondisi di lapangan yang sebenarnya(Amalia et al., 2019). De Angelo (1981) memberikan definisi bahwa kualitas audit adalah kondisi dimana auditor dapat menemukan serta melaporkan pelanggaran yang terjadi pada sistem akuntansi.

Faktor penting yang dapat memengaruhi kualitas audit adalah skeptisisme profesional. Skeptisisme profesional dalam Standar Pemeriksaan Keuangan Negara (SPKN) memiliki arti sebagai sikap yang selalu mempertanyakan sertamelakukan evaluasi dengan kritis terhadap bukti 
pemeriksaan atau hal-hal lain selama proses pemeriksaan.Sikap skeptisisme profesional harus dimiliki oleh seorang auditor dikarenakan skeptisisme atau keingintahuan auditor akan mampu meningkatkan kualitas audit. Mengingat rasa keingintahuan auditor yang tinggi, auditor akan memiliki kemampuan untuk mengevaluasi bukti audit sehingga akan mampu menemukan pelanggaran keuangan dan penipuan apapun yang dilakukan oleh klien (Mardijuwono \& Subianto, 2018). Nihestita et al., (2018) dalam penelitiannya menemukan hasil yakni skeptisisme profesional berpengaruh terhadap kualitas audit. Sedangkan Nandari \& Latrini (2015) memperoleh hasil penelitian yaitusikap skeptis tidak memiliki pengaruh terhadap kualitas audit.

Faktor lainnya yang penting terhadap kualitas audit adalah due professional care. Pernyataan standar umum ketiga dalam Peraturan BPK No.1 menyatakan bahwa pemeriksa wajib menggunakan kemahiran profesionalnya dalam melaksanakan proses pemeriksaan dan pada proses penyusunan laporan hasil pemeriksaan tersebut (Badan Pemeriksa Keuangan, 2007). Due professional care adalah kemahiran profesional secara cermat dan saksama dengan berpikir kritis dalam mengevaluasi bukti audit serta bersikaphati-hati dalam melaksanakan tugas audit. Penelitian Savitri \& Dwirandra (2018) menyatakan bahwakualitas audit secara positif dipengaruhi olehdue professional care. Sedangkan Randi (2014) menemukan hasil yaitu kualitas audit tidak dipengaruhi oleh due professional care.

Faktor selanjutnya yang memengaruhi kualitas audit adalah tekanan anggaran waktu (time budget pressure). Anggaran waktu (time budget) adalah perkiraan waktu yang dibutuhkan untuk melakukan setiap langkah dalam audit (Whittington \& Pany, 2016:227). Tekanan anggaran waktu adalah kondisi pada saat auditor berada dalam tekanan untuk menyelesaikan penugasan audit sesuai dengan anggaran yang telah disepakati (Said \& Munandar, 2019). Penelitian oleh Deviani \& Badera (2017) memperoleh hasil bahwa secara negatif dan signifikan kualitas audit dipengaruhi oleh tekanan anggaran waktu. Berbanding terbalik hasil temuan E. Wijaya (2018) yang menyatakan hasil bahwa tekanan anggaran waktu berpengaruh positif terhadap kualitas audit.

Berdasarkan penelitian sebelumnya yang masih terdapat perbedaan hasil, maka peneliti ingin meneliti kembali pengaruh skeptisisme profesional, due professional care, dan tekanan anggaran waktupada kualitas audit. Oleh karena itu penulis mengangkat judul "Pengaruh Skeptisisme Profesional, Due Professional Care, dan Tekanan Anggaran Waktupada Kualitas Audit (Studi Empiris pada Badan Pemeriksa Keuangan Perwakilan Provinsi Bali)".

Berdasarkan latar belakang diatas, rumusan masalah dalam penelitian ini adalah bagaimana pengaruh skeptisisme profesional, due professional care, dan tekanan anggaran waktu pada kualitas audit? Tujuan dilakukannya penelitian ini adalah untuk memberikan bukti secara empiris pengaruh skeptisisme profesional, due professional care, dan tekanan anggaran waktu pada kualitas audit.

Teori keagenan adalah teori yang menjelaskan tentang terjadinya suatu konflik antara manajemen selaku agen dengan pemilik selaku principal. Teori keagenan dikemukakan oleh Jensen \& Meckling (1976) sebagai suatu kontrak yang terjadi antara principaldengan agen, dimana agen sebagai pihak yang 
ditugaskan dalam melaksanakan beberapa layanan bagi principal dan juga diberikan wewenang pengambilan keputusan. Dalam ruang lingkup pemerintahan, masalah keagenan muncul antara legislatif dengan eksekutif atau antara publik (masyarakat) dengan legislatif. Dalam konteks pembuatan kebijakan, hubungan principal-agen yang terjadi adalah publik sebagai principal dan legislatif sebagai agen. Hubungan principal-agen ini dimulai pada saat masyarakat memilih anggota legislatif yang selanjutnya akan membuat keputusan tentang belanja publik untuk masyarakat, lalu masyarakat akan memberikan dana melalui pembayaran pajak. Ketika legislatif kemudian terlibat dalam pembuatan keputusan atas pengalokasian belanja dalam anggaran, maka legislatif diharapkan mewakili kepentingan principal atau pemilihnya. Dalam teori ini, terdapat pihak independen untuk menengahi konflik yang terjadi. Auditor adalah pihak independen yang berfungsi sebagai pihak yang membantu memahami konflik kepentingan yang muncul antara principal dan agen.

Teori atribusi dicetuskan Heider (1958). Teori atribusi merupakan teori yang menjelaskan tentang perilaku seseorang. Teori ini menjelaskan penyebab perilaku orang lain atau dirinya sendiri ditentukan oleh faktor internal ataupun faktor eksternal. Faktor internal adalah faktor yang berasal dari dalam diri seseorang, sedangkan faktor eksternal merupakan faktor yang berasal dari luar. Teori atribusi digunakan untuk mendukung faktor-faktor yang memengaruhi auditor dalam menghasilkan kualitas audit.

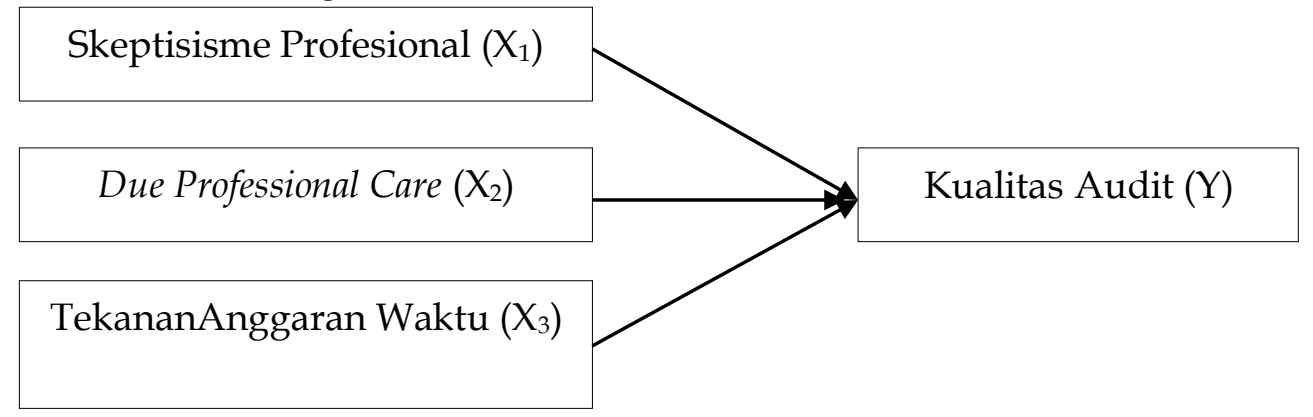

Sumber: Data Penelitian, 2019

Gambar 1. Kerangka Konseptual

Skeptisisme profesional adalah sikap yang selalu mempertanyakan serta melakukan evaluasi dengan kritis terhadap bukti pemeriksaan atau hal-hal lain selama proses pemeriksaan. Penelitian yang dilakukan oleh Rossita \& Sukartha (2017) menyatakan bahwa skeptisisme profesional berpengaruh positif pada kualitas audit, dimana kualitas audit yang semakin baik maka skeptisisme profesional yang dimiliki oleh auditor juga semakin tinggi. Penelitian yang dilakukan oleh Wijaya \& Suputra (2018) juga menunjukkan hasil yang sama yaitu skeptisime profesional berpengaruh positif pada kualitas audit. Dalam meningkatkan kualitas audit, sikap skeptisisme profesional sangat dibutuhkan karena dapat membuat auditor lebih kritis dalam penilaian terhadap bukti-bukti audit dan lebih berinisiatif untuk mencari lebih dalam informasi yang berasal dari manajemen agar auditor dapat membuat keputusan yang sesuai.Berdasarkan hasil penelitian terdahulu dan teori yang sudah dijelaskan, maka hipotesis yang ditetapkan adalah sebagai berikut:

$\mathrm{H}_{1}$ : Skeptisisme profesional berpengaruh positif pada kualitas audit. 
Due professional care diartikan sebagai kecermatan dan kesaksamaan dalam penggunaan kemahiran profesional yang menuntut seorang auditor untuk melakukan skeptisisme profesional.Penelitian yang dilakukan oleh Pranadata \& Badera (2016) menunjukkan hasil bahwa due professional care berpengaruh positif pada kualitas audit. Ningrum dan Budiartha (2017) menyatakan bahwa due professional care berpengaruh positif pada kualitas audit.

Penelitian yang dilakukan Dewi \& Sudana (2018) juga menunjukkan hasil yang sama yaitu due professional care berpengaruh positif dan signifikan pada kualitas audit. Auditor yang menerapkan due professional care akan memperoleh keyakinan bahwa salah saji material dalam laporan bisa terdeteksi. Berdasarkan hasil penelitian terdahulu dan teori yang sudah dijelaskan, maka hipotesis yang ditetapkan adalah sebagai berikut:

$\mathrm{H}_{2}$ : Due professional care berpengaruh positif pada kualitas audit.

Tekanan anggaran waktu (time budget pressure) adalah keadaan dimana auditor dituntut untuk melakukan penugasan audit sesuai dengan anggaran waktu yang telah disusun.Penelitian yang dilakukan oleh Santhi \& Ratnadi (2017) menunjukkan bahwa tekanan anggaran waktuberpengaruh negatif pada kualitas audit. Deviani \& Badera (2017) menyatakan bahwa tekanan anggaran waktuberpengaruh negatif dan signifikan pada kualitas audit, kondisi ini menggambarkan semakin tinggi tekanan anggaran waktumaka semakin rendah kualitas audit yang dihasilkan. Penelitian yang dilakukan oleh Riyandari \& Badera (2017) juga menunjukkan hasil yang sama bahwa tekanan anggaran waktuberpengaruh negatif dan signifikan pada kualitas audit. Tekanan anggaran waktu yang tinggi menyebabkan auditor meningkatkan efisiensi dalam melaksanakan proses audit sehingga pelaksanaan audit tidak berdasarkan pada prosedur yang sesuai dengan ketentuan yang berlaku.Berdasarkan hasil penelitian terdahulu dan teori yang sudah dijelaskan, maka hipotesis yang ditetapkan adalah sebagai berikut:

$\mathrm{H}_{3}$ : Tekanan anggaran waktu berpengaruh negatif pada kualitas audit.

\section{METODE PENELITIAN}

Peneliti dalam penelitian ini menggunakan pendekatan kuantitatif yang berbentuk penelitian asosiatif. Penelitian asosiatif merupakanpenelitian yang memiliki tujuan untuk mengetahui hubungan antara dua variabel atau lebih. Penelitian ini dilakukan di Kantor Badan Pemeriksa Keuangan (BPK) RI Perwakilan Provinsi Bali yang beralamat di Jalan Panjaitan No.2, Sumerta Kelod, Kecamatan Denpasar Timur, Kota Denpasar, Bali.

Populasi dalam penelitian ini adalah seluruh auditor di Kantor BPK RI Perwakilan Provinsi Bali yang berjumlah 52 orang. Metode penentuan sampel yang digunakan dalam penelitian ini adalah Non Probability Sampling dengan menggunakan teknik sampling jenuh. Sampling jenuh adalah teknik penentuan sampel bila semua anggota populasi digunakan sebagai sampel.Metode pengumpulan data yang digunakan adalah metode survei dengan teknik kuesioner, yaitu teknik pengumpulan data dengan cara memberi pertanyaan atau pernyataan tertulis kepada responden. Jawaban pernyataan responden diukur dengan menggunakan skala likert 4 (empat) poin. 
Analisis regresi linier berganda dalam peneltiian ini merupakan teknik analisis utama untuk menjawab hipotesis penelitian. Sebelum melakukan pengujian regresi, dilakukan uji validitas dan reliabilitas terlebih dahulu. Selanjutnya dilanjutkan dengan uji asumsi klasik (uji normalitas, uji multikolinearitas, uji heteroskedastisitas), dan uji statistik deskriptif. Adapun bentuk persamaan regresi linier berganda yang digunakan yakni sebagai berikut:

$Y=\alpha+\beta_{1} X_{1}+\beta_{2} X_{2}+\beta_{3} X_{3}+\varepsilon$

Keterangan:

Y : Kualitas Audit

a $\quad$ : Konstanta

$\beta_{1}, \beta_{2}, \beta_{3}$ :Koefisien Regresi dari Skeptisisme Profesional $\left(X_{1}\right)$,Due Professional Care $\left(\mathrm{X}_{2}\right)$ danTekanan Anggaran Waktu $\left(\mathrm{X}_{3}\right)$

$\mathrm{X}_{1} \quad$ :Skeptisisme Profesional

$\mathrm{X}_{2} \quad$ : Due Professional Care

$\mathrm{X}_{3} \quad$ : Tekanan Anggaran Waktu

$\varepsilon \quad:$ Error

\section{HASIL DAN PEMBAHASAN}

Jumlah auditor padaKantor BPK RI Perwakilan Provinsi Bali adalah 52 orang. Kuesioner dibagikan kepada seluruh auditor yang berada BPK RI Perwakilan Provinsi Bali. Teknik sampling jenuh merupakan metode penentuan sampel yang digunakan dalam penelitian ini. Sampel dalam penelitian ini adalah seluruh auditor yang berada di BPK RI Perwakilan Provinsi Bali yang berjumlah 52 orang.

Kuesioner dibagikan kepada seluruh auditor yang berada di BPK RI Perwakilan Provinsi Bali yang berjumlah 52 orang. Tetapi, dari 52 kuesioner yang dibagikan kepada seluruh auditor BPK RI Perwakilan Provinsi Bali, terdapat 10 kuesioner yang tidak diisi dikarenakan auditor memiliki kesibukan pekerjaan. Maka, jumlah kuesioner yang dapat diolah hanya 42 kuesioner atau setara dengan $80,77 \%$.

Analisis statistik deskriptif merupakan penjelasan dari suatu data pada variabel penelitian yang didasarkan pada jumlah sampel, nilai minimum, nilai maksimum, nilai rata-rata (mean), dan standar deviasi. Hasil statistik deskriptif dijelaskan pada Tabel 1.

Tabel 1. Hasil Statistik Deskriptif

\begin{tabular}{llllll}
\hline Variabel & N & Min. & Max. & Mean & Std. Deviasi \\
\hline Skeptisisme Profesional & 42 & 18,00 & 24,00 & 21,26 & 1,69 \\
Due Professional Care & 42 & 30,00 & 40,00 & 35,81 & 3,23 \\
Tekanan Anggaran Waktu & 42 & 10,00 & 14,00 & 12,00 & 1,21 \\
Kualitas Audit & 42 & 16,00 & 22,00 & 20,05 & 1,92 \\
\hline
\end{tabular}

Sumber: Data Penelitian, 2019

Berdasarkan Tabel 1. skeptisisme profesional $\left(X_{1}\right)$ memiliki nilai terendah 18,00, nilai tertinggi 24,00, nilai rata-rata (mean) 21,26, dan standar deviasi 1,69. Hal ini menunjukkan bahwa standar penyimpangan data terhadap nilai rataratanya adalah 1,69 . Due professional care $\left(X_{2}\right)$ memiliki nilai terendah 30,00 , nilai tertinggi 40,00, nilai rata-rata (mean) 35,81, dan standar deviasi 3,23. Hal ini menunjukkan bahwa standar penyimpangan data terhadap nilai rata-ratanya 
adalah 3,23. Tekanan anggaran waktu $\left(X_{3}\right)$ memiliki nilai terendah 10,00 , nilai tertinggi 14,00, nilai rata-rata (mean) 12,00, dan standar deviasi 1,21. Hal ini menunjukkan bahwa standar penyimpangan data terhadap nilai rata-ratanya adalah 1,21 .

Uji normalitas digunakan untuk menguji apakah model regresi yang dibuat berdistribusi normal atau tidak. Hasil uji normalitas ditunjukkan pada Tabel 2.

\section{Tabel 2. Hasil Uji Normalitas}

\begin{tabular}{ll}
\hline & Unstandardized Residual \\
\hline $\mathrm{N}$ & 42 \\
Kolmogorov-Smirnov Z & 0,645 \\
Asymp.Sig.(2-tailed) & 0,800 \\
\hline
\end{tabular}

Sumber: Data Penelitian, 2019

Berdasarkan Tabel 2. didapatkan nilai Asymp. Sig (2-tailed) sebesar 0,800 dimana nilai ini lebih besar dari 0,05 , maka dapat disimpulkan bahwa model persamaan regresi sudah berdistribusi normal.

Uji multikolinearitas digunakan untuk menguji ada tidaknya korelasi antar variabel bebas pada model regresi. Hasil uji multikolinearitas ditunjukkan pada Tabel 3.

Tabel 3. Hasil Uji Multikolinearitas

\begin{tabular}{llll}
\hline Variabel & Tolerance & VIF & Keterangan \\
\hline Skeptisisme Profesional $\left(\mathrm{X}_{1}\right)$ & 0,997 & 1,003 & $\begin{array}{l}\text { Bebas } \\
\text { multikolinearitas }\end{array}$ \\
Due Professional Care $\left(\mathrm{X}_{2}\right)$ & 0,967 & 1,034 & $\begin{array}{l}\text { Bebas } \\
\text { multikolinearitas }\end{array}$ \\
Tekanan Anggaran Waktu $\left(\mathrm{X}_{3}\right)$ & 0,967 & 1,034 & $\begin{array}{l}\text { Bebas } \\
\text { multikolinearitas }\end{array}$ \\
\hline
\end{tabular}

Sumber: Data Penelitian, 2019

Berdasarkan Tabel 3. dapat dilihat bahwa nilai tolerance untuk setiap variabel lebih besar dari 10\% dan nilai VIF lebih kecil dari 10 yang berarti model regresi bebas dari multikolinearitas.

Uji heteroskedastisitas pada penelitian ini menggunakan uji Glejser. Jika variabel bebas yang diteliti mempunyai nilai signifikansi lebih dari 0,05, maka model regresi tidak mengandung gejala heteroskedastisitas. Hasil uji heteroskedastisitas ditunjukkan pada Tabel 4.

Tabel 4. Hasil Uji Heteroskedastisitas

\begin{tabular}{lll}
\hline Variabel & Sig. & Keterangan \\
\hline Skeptisisme Profesional $\left(\mathrm{X}_{1}\right)$ & 0,076 & Bebas heteroskedastisitas \\
Due Professional Care $\left(\mathrm{X}_{2}\right)$ & 0,160 & Bebas heteroskedastisitas \\
Tekanan Anggaran Waktu $\left(\mathrm{X}_{3}\right)$ & 0,697 & Bebas heteroskedastisitas \\
\hline
\end{tabular}

Sumber: Data Penelitian, 2019

Berdasarkan Tabel 5. dilihat bahwa nilai Sig. dari variabel skeptisisme profesional, due professional care, dan tekanan anggaran waktu, masing-memiliki nilai yang lebih besar dari 0,05. Hal ini berarti model yang dibuat tidak mengandung gejala heteroskedastisitas.

Hasil analisis regresi linier berganda bertujuan untuk mengetahui hubungan variabel skeptisme profesionalisme, due professional care dan tekanan 
anggaran waktu terhadap kualitas audit, dan secara rinci ditunjukkan pada Tabel 5.

Tabel 5. Hasil Regresi Linier Berganda

\begin{tabular}{|c|c|c|c|c|c|}
\hline \multirow[t]{2}{*}{ Model } & \multicolumn{2}{|c|}{$\begin{array}{l}\text { Unstandardized } \\
\text { Coefficients }\end{array}$} & \multirow{2}{*}{$\begin{array}{l}\text { Standardized } \\
\text { Coefficients } \\
\text { Beta }\end{array}$} & \multirow[t]{2}{*}{$\mathrm{T}$} & \multirow[t]{2}{*}{ Sig, } \\
\hline & $\mathrm{B}$ & Std. Error & & & \\
\hline (Constant) & 9,588 & 4,192 & & 2,287 & 0,028 \\
\hline Skeptisisme & 0,593 & 0,123 & 0,519 & 4,802 & 0,000 \\
\hline Profesional & & & & & \\
\hline Due Professional Care & 0,164 & 0,066 & 0,275 & 2,502 & 0,017 \\
\hline $\begin{array}{l}\text { Tekanan Anggaran } \\
\text { Waktu }\end{array}$ & $-0,670$ & 0,175 & $-0,421$ & $-3,836$ & 0,000 \\
\hline Adjusted R Square & & 0,523 & & & \\
\hline $\mathrm{F}$ & & 15,956 & & & \\
\hline Sig. & & $0,000^{a}$ & & & \\
\hline
\end{tabular}

Sumber: Data Penelitian, 2019

Berdasarkan Tabel 5. dapat disusun bentuk persamaan regresi linier berganda sebagai berikut:

$$
Y=9,588+0,593 X_{1}+0,164 X_{2}-0,670 X_{3}+\varepsilon
$$

Hasil analisis pengaruh skeptisisme profesional pada kualitas audit didapatkan nilai signifikansi sebesar 0,000 dengan nilai koefisien regresi positif sebesar 0,593. Nilai signifikansi sebesar 0,000 lebih kecil dari 0,05 mengindikasikan bahwa $\mathrm{H}_{1}$ diterima, artinyaskeptisisme profesional berpengaruh positif dan signifikan terhadap kualitas audit pada Kantor Badan Pemeriksa Keuangan (BPK) RI Perwakilan Provinsi Bali. Hasil analisis pengaruh due professional care terhadap kualitas audit didapatkan nilai signifikansi sebesar 0,017 dengan nilai koefisien regresi positif sebesar 0,164. Nilai signifikansi sebesar 0,017 lebih kecil daripada 0,05 mengindikasikan bahwa $\mathrm{H}_{2}$ diterima, artinya due professional care berpengaruh positif dan signifikan terhadap kualitas audit pada Kantor Badan Pemeriksa Keuangan (BPK) RI Perwakilan Provinsi Bali. Hasil analisis pengaruh tekanan anggaran waktu terhadap kualitas audit didapatkan nilai signifikansi sebesar 0,000 dengan nilai koefisien negatif sebesar 0,670. Nilai signifikansi sebesar 0,000 lebih kecil daripada 0,05 mengindikasikan bahwa $\mathrm{H}_{3}$ diterima, artinya tekanan anggaran waktu berpengaruh negatif dan signifikan terhadap kualitas audit pada Kantor Badan Pemeriksa Keuangan (BPK) RI Perwakilan Provinsi Bali.

Berdasarkan Tabel 5. menunjukkan bahwa nilai Adjusted $R^{2}$ sebesar 0,523, dimana mempunyai arti bahwa sebesar $52,3 \%$ variasi kualitas audit pada Kantor Badan Pemeriksa Keuangan (BPK) RI Perwakilan Provinsi Bali dipengaruhi oleh variasi skeptisisme profesional, due professional care, dan tekanan anggaran waktu. Sedangkan, sisanya sebesar $47,7 \%$ dijelaskan oleh faktor lain yang tidak dimasukkan ke dalam model.

Berdasarkan Tabel 5. diperoleh nilai Fsebesar 15,956 dengan nilai Sig. sebesar $0,000<0,05$, maka dapat disimpulkan bahwa pada kelompok yang diuji memiliki perbedaan yang nyata atau signifikan. Hasil ini mempunyai arti bahwa secara simultan skeptisisme profesional, due professional care, dan tekanan anggaran waktu berpengaruh signifikan terhadap kualitas audit pada Badan Pemeriksa Keuangan (BPK) RI Perwakilan Provinsi Bali. 
Hasil analisis pengaruh skeptisisme profesional terhadap kualitas audit, menunjukkan nilai signifikansi sebesar 0,000 dengan nilai koefisien regresi 0,593. Nilai signifikansi 0,000 $<0,05$ memiliki makna $\mathrm{H}_{0}$ ditolak dan $\mathrm{H}_{1}$ diterima, yang artinya skeptisisme profesional berpengaruh positif dan signifikan terhadap kualitas audit. Semakin tingginya skeptisisme profesional yang dimiliki oleh auditor, maka auditor akan lebih kritis terhadap penilaian bukti-bukti audit serta akan selalu mempertanyakan kehandalan bukti-bukti audit tersebut, sehingga auditor dapat menghasilkan kualitas audit yang baik. Hasil penelitian ini konsisten dengan penelitian yang dilakukan oleh Rossita \& Sukartha (2017) serta Wijaya \& Suputra (2018).

Hasil analisis pengaruh due professional care terhadap kualitas audit, menunjukkan nilai signifikansi sebesar 0,017 dengan nilai koefisien regresi 0,164. Nilai signifikansi 0,017 < 0,05 memiliki makna $\mathrm{H}_{0}$ ditolak dan $\mathrm{H}_{2}$ diterima, yang artinya due professional care berpengaruh positif dan signifikan terhadap kualitas audit. Semakin tingginya due professional care yang dimiliki oleh auditor membuktikan bahwa auditor telah menggunakan kemahiran profesionalnya secara cermat dan saksama dalam melakukan proses audit, sehingga auditor akan menghasilkan kualitas audit yang baik.Hasil penelitian ini konsisten dengan penelitian yang dilakukan oleh Ningrum \& Budiartha (2017) serta Dewi \& Sudana (2018).

Hasil analisis pengaruh tekanan anggaran waktu terhadap kualitas audit yang dijelaskan pada Tabel 5. menunjukkan nilai signifikansi sebesar 0,000 dengan nilai koefisien regresi $-0,670$. Nilai signifikansi $0,000<0,05$ memiliki makna $\mathrm{H}_{0}$ ditolak dan $\mathrm{H}_{3}$ diterima, yang artinya tekanan anggaran waktu berpengaruh negatif dan signifikan terhadap kualitas audit, dimana ini berarti semakin tingginya tekanan anggaran waktu yang dimiliki oleh auditor akan menyebabkan auditor meningkatkan efisiensi dalam proses audit yang dilaksanakan. Efisiensi ini akan menyebabkan pelaksanaan audit tidak berdasarkan pada prosedur maupun ketentuan yang berlaku sehingga kualitas audit yang dihasilkan akan semakin rendah. Hasil penelitian ini konsisten dengan penelitian yang dilakukan oleh Deviani \& Badera (2017) serta Riyandari \& Badera (2017)

Penelitian ini mendukung teori keagenan yang diungkapkan oleh Jensen \& Meckling (1976) yang menyatakan bahwa teori keagenan sebagai suatu kontrak antara satu atau lebih principal yang melibatkan agen untuk melaksanakan beberapa layanan bagi mereka dengan memberikan pendelegasian wewenang pengambilan keputusan kepada agen. Teori keagenan menjelaskan konflik yang terjadi antara principal dan agen. Auditor sebagai pihak independen membantu memahami konflik kepentingan yang muncul antara principal dan agen. Dalam hal ini, menghasilkan kualitas audit yang baik merupakan tanggung jawab seorang auditor guna menengahi konflik kepentingan tersebut. Dalam tingkat pemerintahan, auditor di Badan Pemeriksa Keuangan (BPK) RI merupakan pihak ketiga yang membantu memahami konflik kepentingan antara principal yaitu publik (masyarakat) dengan agen yaitu legislatif (pejabat pemerintahan). Untuk mengurangi konflik yang ada, auditor dituntut untuk melakukan audit atas laporan keuangan yang disajikan oleh 
pejabat pemerintahan untuk memberikan bukti kepada masyarakat bahwa laporan keuangan yang disajikan tidak terdapat kecurangan.

Selain teori keagenan, penelitian ini juga mendukung teori atribusi oleh Heider (1958) yang menjelaskan tentang penyebab perilaku orang lain atau dirinya sendiri yang ditentukan oleh faktor internal ataupun faktor eksternal. Faktor internal merupakan faktor yang berasal dari dalam diri seseorang, sedangkan faktor eksternal merupakan faktor yang berasal dari luar diri seseorang. Dalam hal menghasilkan kualitas audit yang baik, faktor internal dan eksternal sangat memengaruhi seorang auditor. Faktor-faktor dalam diri seorang auditor (faktor internal) yaitu skeptisisme profesional dan due professional care berpengaruh positif pada kualitas audit. Sedangkan, faktor dari luar diri seorang auditor (faktor eksternal) berpengaruh negatif pada kualitas audit.

Bagi peneliti, penelitian ini dapat menambah wawasan tentang faktorfaktor yang memengaruhi kualitas audit pada BPK RI Perwakilan Provinsi Bali, sedangkan bagi pihak-pihak yang berkepentingan, penelitian ini dapat dijadikan acuan untuk penelitian-penelitian selanjutnya. Bagi para profesi auditor yang berada di BPK RI Perwakilan Provinsi Bali, penelitian ini dapat memberikan informasi guna menjadi pertimbangan dalam menghasilkan kualitas audit yang baik dengan tetap menjunjung tinggi skeptisisme profesional dan due professional care serta patuh pada anggaran waktu yang ditetapkan tanpa mengurangi prosedur audit yang telah ditetapkan.

\section{SIMPULAN}

Berdasarkan hasil analisis dan pembahasan, maka dapat diperoleh simpulan bahwa skeptisisme profesional dan due professional care berpengaruh positif dan signifikan terhadap kualitas audit pada BPK RI Perwakilan Provinsi Bali. Sedangkan, tekanan anggaran waktu berpengaruh negatif dan signifikan terhadap kualitas audit pada BPK RI Perwakilan Provinsi Bali.

Saran yang dapat diberikan berdasarkan hasil penelitian adalah auditor yang berada di BPK RI Perwakilan Provinsi Bali diharapkan untuk lebih meningkatkan sikap skeptisime profesional serta due professional care yang dimilikinya agar bisa selalu meningkatkan kualitas audit yang dihasilkan. Selain itu, diharapkan juga mampu melaksanakan proses audit sesuai dengan prosedur yang seharusnya walaupun adanya tekanan anggaran waktu agar kualitas audit yang dihasilkan meningkat. Saran bagi penelitian selanjutnya, diharapkan diharapkan menambah variabel-variabel lain yang dapat memengaruhi variabel dependen.

\section{REFERENSI}

Amalia, F. A., Sutrisno, \& Baridwan, Z. (2019). Audit Quality: Does Time Pressure Influence Independence and Audit Procedure Compliance of Auditor? Journal of Accounting and Investment, 20(1), 130-144. https:// doi.org/10.18196/jai.2001112

Badan Pemeriksa Keuangan. Peraturan Badan Pemeriksaan Keuangan Republik Indonesia No. 01 Tahun 2007 Tentang Standar Pemeriksaan Keuangan (2007). Indonesia. Retrieved from 
https:/ / peraturan.bpk.go.id/Home/Details/5/peraturan-bpk-no-1tahun-2007

De Angelo, L. E. (1981). Auditor Size and Audit Quality. Journal of Accounting and Economics, 3, 183-199. https:/ / doi.org/10.1016/0165-4101(81)90002-1

Deviani, T., \& Badera, I. D. N. (2017). Sistem Informasi sebagai Pemoderasi Pengaruh Kompleksitas Audit dan Time Budget Pressure terhadap Kualitas Audit. E-Jurnal Akuntansi Universitas Udayana, 18(2), 1171-1201.

Dewi, N. M. W. I., \& Sudana, I. P. (2018). Pengaruh Pengalaman, Due Professional Care dan Akuntabilitas Auditor pada Kualitas Audit. EJurnal Akuntansi Universitas Udayana, 22(1), 438-463. https:// doi.org/https://doi.org/10.24843/EJA.2018.v22.i01.p17

Ghafran, C., \& O'Sullivan, N. (2017). The Impact of Audit Committee Expertise on Audit Quality: Evidence from UK Audit Fees. British Accounting Review, 49(6), 578-593. https:/ / doi.org/10.1016/j.bar.2017.09.008

Haryadi, M. (2017). ICW: Ada 6 Kasus Suap yang Melibatkan Oknum Pejabat BPK dalam Kurun Waktu 2015-2017. Tribunnews.Com. Retrieved from https://www.tribunnews.com/nasional/2017/05/27/icw-ada- 6-kasussuap-yang-melibatkan-oknum-pejabat-bpk-dalam-kurun-waktu-20152017.

Heider, F. (1958). The Psychology of Interpersonal Relations. New York: Wiley.

Jensen, M. C., \& Meckling, W. H. (1976). Theory of the Firm: Managerial Behavior, Agency Costs and Ownership Structure. Journal of Financial Economics, 3, 305-360. https://doi.org/http://dx.doi.org/10.1016/0304405X(76) $90026-X$

Jusup, A. H. (2014). buku audit-converted.pdf. Yogyakarta: Bagian Penerbitan Sekolah Tinggi Ilmu Ekonomi YKPN.

Mardijuwono, A. W., \& Subianto, C. (2018). Independence, Professionalism, Professional Skepticism (The Relation Toward the Resulted Audit Quality). Asian Journal of Accounting Research, 3(1), 61-71. https:/ / doi.org/10.1108/ajar-06-2018-0009

Nandari, A. W. S., \& Latrini, M. Y. (2015). Pengaruh Sikap Skeptis, Independensi, Penerapan Kode Etik, Dan Akuntabilitas Terhadap Kualitas Audit. EJurnal Akuntansi Universitas Udayana, 10(1), 164-181.

Nihestita, Rosini, I., Hakim, D. R., \& Kurniawati, D. (2018). Pengaruh Integritas dan Skeptisme Profesional Auditor terhadap Kualitas Audit (Studi Kasus Pada Kantor Akuntan Publik Jakarta Selatan). National Conference of Creative Industry, (September), 5-6. https:// doi.org/10.30813/ncci.v0i0.1304

Ningrum, M. K. K., \& Budiartha, K. (2017). Etika Auditor Memoderasi Pengaruh Pengalaman Auditor, Kompetensi Dan Due Professional Care Pada Kualitas Audit. E-Jurnal Akuntansi Unversitas Udayana, 20(1), 615-644. Retrieved from https://ojs.unud.ac.id/index.php/Akuntansi/article/view/29404/1936 7.

Pranadata, I. N. W. B., \& Badera, I. D. N. (2016). Pengaruh Kompetensi, Due Professional Care, Pengalaman Kerja, dan Besaran Fee Audit pada Kualitas Audit. E-Jurnal Akuntansi Universitas Udayana, 17(3), 1981-2007. 
Randi, S. V. (2014). Pengaruh Kompetensi, Independensi, Akuntabilitas, Pengalaman, Due Professional Care dan Motivasi terhadap Kualitas Audit. Fakultas Ekonomi Dan Bisnis Jurusan Akuntansi Universitas Muhammadiyah Surakarta.

Riyandari, P. K., \& Badera, I. D. N. (2017). Pengalaman Auditor Sebagai Pemoderasi Pengaruh Time Budget Pressure Dan Kompleksitas Audit Pada Kualitas Audit. E-Jurnal Universitas Udayana, 19(2302-8556), 195222.

Rossita, N. M. D., \& Sukartha, I. M. (2017). Pengaruh Kompetensi, Komitmen Organisasi, Skeptisme Profesional dan Motivasi Pada Kualitas Audit. EJurnal Akuntansi, 20(3), 2539-2565. Retrieved from https://ojs.unud.ac.id/index.php/Akuntansi/article/view/31805

Said, L. L., \& Munandar, A. (2019). The Influence of Auditor's Professional Skepticism and Competence on Fraud Detection: the Role of Time Budget Pressure. Jurnal Akuntansi Dan Keuangan Indonesia, 15(1), 104120. https:// doi.org/10.21002/jaki.2018.06

Santhi, L. G. M. W., \& Ratnadi, N. M. D. (2017). Independensi Auditor sebagai Pemediasi Pengaruh Audit Fee dan Time Budget Pressure pada Kualitas Audit. E-Jurnal Akuntansi Universitas Udayana, 19(3), 2059-2089.

Savitri, P. D. I., \& Dwirandra, A. A. N. B. (2018). Time Budget Pressure sebagai Pemoderasi Pengaruh Due Professional Care dan Pengalaman Audit pada Kualitas Audit. E-Jurnal Akuntansi Universitas Udayana, 22(2), 11121140. https:// doi.org/https:/ / doi.org/10.24843/EJA.2018.v22.i02.p11

Whittington, O. R., \& Pany, K. (2016). Principles of Auditing \& Other Assurance Services (Twentieth). New York, NY 10121: McGraw-Hill Education.

Wijaya, E. (2018). Pengaruh Independensi, Kompetensi dan Tekanan Anggaran Waktu terhadap Kualitas Audit dengan Etika Auditor sebagai Variabel Moderasi (Studi pada Auditor Kantor Akuntan Publik di Jawa Tengah dan DIY). Universitas Stikubank. Universitas Stikubank Semarang.

Wijaya, P. G. P., \& Suputra, I. D. G. D. (2018). Pengaruh Problem Solving Ability, Independensi dan Skeptisme Profesional Auditor terhadap Kualitas Audit. E-Jurnal Akuntansi Universitas Udayana, 23(3), 1819-1843. https:// doi.org/https://doi.org/10.24843/EJA.2018.v23.i03.p08 